\section{Surface currents and upwelling in Kerguelen Plateau regions}

\section{Surface currents and upwelling in \\ Kerguelen Plateau \\ regions \\ M. Zhou et al.}

M. Zhou ${ }^{1,4}$, Y. Zhu ${ }^{1}$, F. d'Ovidio ${ }^{2}$, Y.-H. Park ${ }^{2}$, I. Durand ${ }^{2}$, E. Kestenare ${ }^{3}$, V. Sanial ${ }^{3}$, P. Van-Beek ${ }^{3}$, B. Queguiner ${ }^{4}$, F. Carlotti ${ }^{4}$, and S. Blain ${ }^{5}$

${ }^{1}$ University of Massachusetts Boston, Boston, MA 02125

${ }^{2}$ LOCEAN-IPSL (CNRS/UPMC/MNHN/IRD), Paris, France

${ }^{3}$ LEGOS (CNRS/UPS/CNES/IRD), Toulouse, France

${ }^{4} \mathrm{MIO}$ (AMU/STVU/CNRS/IRD), Marseille, France

${ }^{5}$ LOMIC (CNRS/UPMC), Banyuls-sur-Mer, France

Received: 7 April 2014 - Accepted: 14 April 2014 - Published: 12 May 2014

Correspondence to: M. Zhou (meng.zhou@ umb.edu)

Published by Copernicus Publications on behalf of the European Geosciences Union.

\section{Title Page}

\section{Abstract}

Conclusions

Tables

14

4

Back

Full Screen / Esc

Printer-friendly Version

Interactive Discussion 


\section{Abstract}

Mean currents, horizontal diffusivity and upwelling on the Kerguelen Plateau and the deep basin east of the Kerguelen Islands were studied using 48 World Ocean Circulation Experiment (WOCE) Standard Surface Velocity Program (SVP) drifters deployed 5 during the 2011 austral spring KEOPS II (KErguelen Ocean Plateau compared Study II) cruise. These drifter data were analyzed based on autocovariances for temporal scales, least-squares fitted streamfunctions for estimating mesoscale mean currents, wind stress fields and Ekman pumping, and Taylor's single particle diffusivity for estimating horizontal dispersion of surface waters. The results have revealed the shelfbreak current on the southern and eastern shelf slopes of the Kerguelen Islands, transport of surface waters from the Kerguelen-Heard shelf basin crossing the shelf slope into the deep basin off the plateau east of the Kerguelen Islands, and upwelling driven by wind stress curl in both the plateau and deep basin regions. The estimated volume transports off the Plateau in the upper $50 \mathrm{~m}$ based on surface drifters and below

\section{Introduction}

The Southern Ocean is the largest High Nutrient Low Chlorophyll (HNLC) region of the world ocean, and the primary production is limited by the availability of dissolved iron (DFe) within surface waters (Martin et al., 1990; Coale et al., 1996). In a few of places, massive phytoplankton blooms are associated with enrichments of DFe by physical processes, such as the Kerguelen Plateau region (Blain et al., 2007; Park et al., 2008),
BGD

$11,6845-6876,2014$

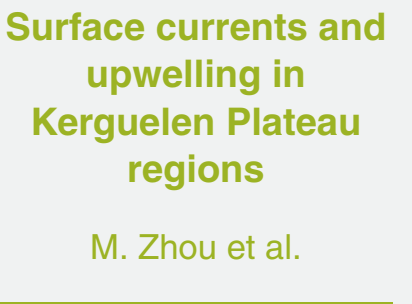

Title Page

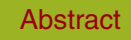

Introduction

Conclusions

Tables

References

Figures

14

4

Back

Close

Full Screen / Esc

Printer-friendly Version

Interactive Discussion 
Crozet Basin (Park et al., 2002; Pollard et al., 2009), Drake Passage and Scotia Sea (Zhou et al., 2010; Measures, 2013), and Ross sea (Orsi and Wiederwohl, 2009; Smith et al., 2012). As both dissolved and particulate iron concentrations in surface waters were depleted, the mechanisms of iron supplies for horizontal and vertical fluxes de5 termine the scale and timing of a bloom which in turn determine the productivity of a pelagic marine ecosystem and export of particulate organic carbon (POC). Estimating iron additions delivered by physical processes into the surface waters becomes a fundamental task in estimating iron-carbon sequestration efficiency and potential total carbon export from nature iron fertilization processes in the Southern Ocean.

10 Dominant physical processes delivering DFe to the surface waters vary in different nature iron fertilization sites. During the 2004 Kerguelen Plateau and Ocean compared Study I (KEOPS I), the low DFe surface water (less than $0.09 \pm 0.034 \mathrm{nM}$ ) on the Kerguelen Plateau was enriched by relatively high DFe waters $(0.19-0.51 \mathrm{nM})$ below $500 \mathrm{~m}$ through vertical mixing process (Blain et al., 2007; Park et al., 2008a). West of periment (CROZEX) showed the importance of both horizontal transport of iron from runoff and vertical mixing of DFe from deep convected waters for fertilizing the surface waters (Charette et al., 2007). In the southern Drake Passage, the DFe-rich shelf water derived from the shelf north of Elephant Island fertilizes the southern Scotia Sea at a horizontal scale of 100-1000 s km (Dulaiova et al., 2009; Hatta et al., 2013; Measures et al., 2013), and the physical mechanisms for such a large scale offshelf iron fertilization were considered as the results of combined topographic steering, Ekman pumping, horizontal mixing between water masses, and potential vorticity conservation (Zhou et al., 2010, 2013; Frants et al., 2013). The horizontal transport can deliver large amount of iron from shelf areas into HNLC regions, but in downstream areas, DFe supplies rely on vertical physical processes or recycling of iron.

The Kerguelen Plateau is a major barrier to the Antarctic Circumpolar Current (ACC) in the Southern Indian Ocean (Fig. 1). The ACC is deflected by this barrier northward (McCartney and Donohue, 2007; Park et al., 2008). In the south, a branch of the
BGD

$11,6845-6876,2014$

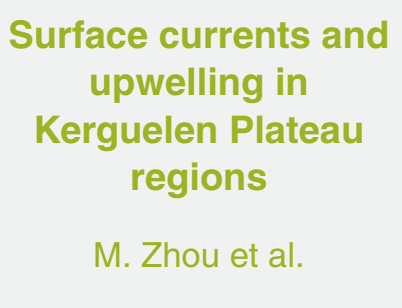

Title Page

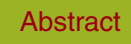

Introduction

Conclusions

Tables

References

Figures

14

4

Back

Full Screen / Esc

Printer-friendly Version

Interactive Discussion 
ACC from the Weddell-Enderby Basin forms the Fawn Trough Current of approximately $14 \mathrm{~Sv}$. It meets the northward western boundary current along the Kerguelen Plateau slope (Gille, 2003; Davis, 2005). As this western boundary current moves northward, it joins the ACC forming the Crozet-Kerguelen Confluence flowing eastward.

5 The ACC surface water west of the Kerguelen Islands is of the typical HNLC water with low DFe while the ACC surface water on the plateau is DFe-enriched with enhanced phytoplankton blooms (Blain et al., 2007). This plateau area between the Kerguelen and Heard Islands, known as the Kerguelen-Heard shelf basin, is considered as a cul de sac with sluggish currents of $3-5 \mathrm{~cm} \mathrm{~s}^{-1}$ but surrounded by strong 10 currents (Park et al., 2008). It was estimated that the vertical mixing can contribute DFe at a rate of only $31 \mathrm{nmolm}^{-2} \mathrm{~d}^{-1}$ for part of the photosynthetic DFe uptake demand of $208 \pm 77 \mathrm{nmol} \mathrm{m}^{-2} \mathrm{~d}^{-1}$ leading to an open unbalanced iron budget. It is even less clear what physical processes contribute to DFe supplies in the deep basin off the plateau east of Kerguelen Islands semi-surrounded by the northeastern shelf slope of the Kerguelen Plateau to its south and west and by the Gallieni Spur to its north (referred as the East Kerguelen Basin hereafter).

The KEOPS II project was aimed at the iron related biogeochemical and biological processes on the Kerguelen Plateau and East Kerguelen Basin off the Plateau. Of critical questions, where are DFe rich shelf waters transported off the Kerguelen Plateau and how is the DFe added into the surface waters in the East Kerguelen Basin? In the 2004 KEOPS I study, the current field in the upper mixed layer was estimated from World Ocean Circulation Experiment (WOCE) Surface Velocity Program (SVP) drifters providing a conceptual circulation pattern consisting of the ACC, and Fawn Trough Current (Park et al., 2008). A number of studies have demonstrated that WOCE SVP drifters can play a primary role in revealing meso- and large-scale circulation in the Southern Ocean (Park et al., 2008; Zhou et al., 2006, 2010, 2013). Working with US National Oceanic and Atmospheric Adiministration (NOAA) Atlantic Oceanographic and Meteorological Laboratory (AOML) Surface Velociy Program Data Assemble Center (DAC), a total of 48 WOCE standard SVP drifters were used in the KEOPS II study.
BGD

$11,6845-6876,2014$

Surface currents and

upwelling in

Kerguelen Plateau

regions

M. Zhou et al.

Title Page

Abstract

Introduction

Conclusions

Tables

References

Figures

14

4

Back $\rightarrow 1$

Full Screen / Esc

Printer-friendly Version

Interactive Discussion 
The objectives using these SVP drifters were to map the large scale circulation pattern and mesoscale fields in the early spring season, and to study horizontal and vertical fluxes of DFe through quantitative estimates of horizontal transport and mixing and vertical upwelling in the East Kerguelen Basin.

\section{Data and methods}

A total of 48 WOCE SVP drifters were deployed during the KEOPS II cruise in October and November 2011 onboard of the RV Marion Dufresne. The locations and identification numbers (IDs) of these drifters are shown in Table 1 and Fig. 2. These drifters used in this study were all mixed-layer drifters that conformed to the WOCE standards in which drogue elements centered at $15 \mathrm{~m}$ provide for the drag area ratio great than 40. These drifters can follow water motion at the center of the drogue within $1 \mathrm{~cm} \mathrm{~s}^{-1}$ error in wind conditions up to $10 \mathrm{~m} \mathrm{~s}^{-1}$ (Sybrandy and Niiler, 1991; Niiler et al., 1987, 1995). Drifters were tracked using the ARGOS onboard polar-orbiting satellites. The position of a drifter was further interpolated to positions every $1 \mathrm{~h}$ based on the optimal we assume the maximum positioning error between two daily fixes is not greater than $800 \mathrm{~m}$, twice the standard deviation, the error of a daily averaged current is expected to be less than $1 \mathrm{cms}^{-1}$, commensurate with the uncertainty.

The temperature and salinity measurements were collected during the KEOPS II cruise using a Seabird 911-plus rosette system with dual conductivity-temperaturedepth (CTD) sensors which were calibrated before and after the cruise (Seabird Electronics Inc., Bellevue, WA, USA). Standard data processing procedures recommended by Seabird Electronics Inc. were applied during post data processing, and the accuracies of temperature, salinity and depth data meet the standards. Because of the limited the $0.25^{\circ} \times 0.25^{\circ}$ wind stress curl data product from the NASA Quick Scatterometer (QuikSCAT) between 1999 and 2007 were used (Risien and Chelton, 2008).

Surface currents and upwelling in Kerguelen Plateau regions

M. Zhou et al.

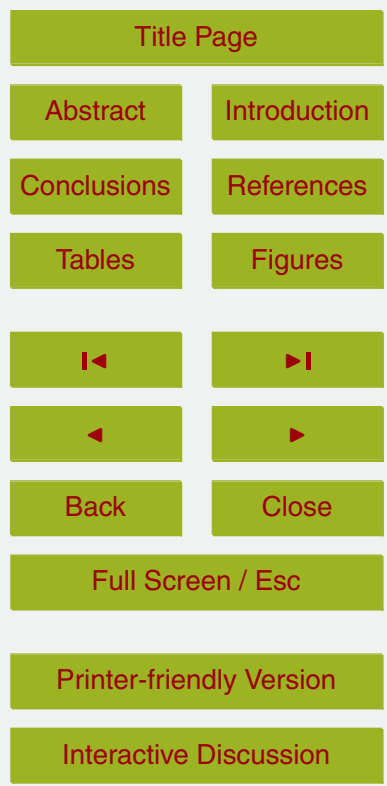

6849 
Following the statistical definitions of drifter motion (Davis, 1991; Zhou et al., 2000), the statistical decorrelation time scale of drifter motion can be estimated from the roll-off of the Lagrangian autocovariance function $R_{i j}(\tau)$ defined as

$R_{i j}(\tau)=\frac{1}{T} \int_{0}^{T} u_{i}^{\prime}(t) u_{i}^{\prime}(t+\tau) \mathrm{d} t \quad(i=x, y)$,

where $u_{i}(i=x, y)$ represents the $u$ and $v$ components of horizontal velocities, $u_{i}^{\prime}=$ $u_{i}-\left\langle u_{i}\right\rangle$ is the perturbation velocity, angle brackets are the ensemble average, $\tau$ is the time lag, and $T$ is the length of the time series. Time-averaged velocities usually substitute the estimates of ensemble-averaged velocities (Poulain and Niiler, 1989). To 10 study the variations of drifter motion, mean motions are removed by applying a highpass-filter with a filter window of 20 days (Fig. 3). The width of the filter window can be determined by trials. The mesoscale variations less than 20 days contribute more than $70 \%$ of kinetic energy. The first zero-crossing of autocovariances is at the 2 days, one order of magnitude less than the filter window applied, and is independent from the filter window selected.

Statistical analysis of mean Taylor's single particle diffusivity can be conducted directly through analyzing variations of Lagrangian properties of drifters as outlined by Davis (1991),

$\kappa_{i j}(\boldsymbol{x}, t)=\left\langle u_{i}^{\prime}\left(t_{0} \mid \boldsymbol{x}, t_{0}\right) d_{j}^{\prime}\left(t_{0}-t \mid \boldsymbol{x}, t_{0}\right)\right\rangle \quad(i, j=x, y)$,

where $\boldsymbol{x}$ is the coordinates $(x, y), u_{i}^{\prime}$ and $d_{j}^{\prime}$ are departures from the Lagrangian mean velocity and displacement, respectively. The notation is such that $u_{i}^{\prime}\left(t \mid x, t_{0}\right)$ is the value $u_{i}^{\prime}(t)$ of the particle passing through $\boldsymbol{x}$ at time $t_{0}$. Furthermore, we approximate eddy diffusivity $\left(\boldsymbol{\kappa}^{\infty}\right)$ as

$\kappa^{\infty}(\boldsymbol{x})=\kappa(\boldsymbol{x}, t \rightarrow \infty) \approx \kappa\left(\boldsymbol{x}, t \rightarrow \tau^{\infty}\right)$,

Surface currents and

upwelling in

Kerguelen Plateau

regions

M. Zhou et al.

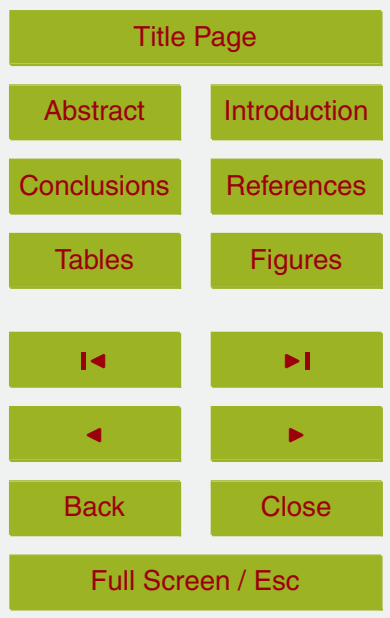

Printer-friendly Version

Interactive Discussion 
where $\tau^{\infty}$ can be approximated using the Lagrangian integral timescale $\left(\tau^{\llcorner}\right)$determined by the integration of Eq. (1), the autocovariance functions (Monin and Yaglom, 1971). Inoue (1950) and Ogura (1952) indicated that $\tau^{\mathrm{L}}<2 \tau^{*}$, where $\tau^{*}$ is satisfied by $R_{i j}\left(\tau^{*}\right)=0$, the zero crossings of the autocovariance functions. The Lagrangian auto-

5 covariance functions of the 20 day filtered data show $\tau^{*}$ approximately equal to 2 days for $R_{x x}$ and $R_{y y}$, respectively. The Lagrangian integral timescale of 4 days is chosen throughout this paper.

Considering that a drifter moves with the water parcel surrounding it, the equation of motion for the water parcel can be written as (Zhou et al., 2000),

${ }_{10}\left\{\begin{array}{l}\frac{\mathrm{d} u}{\mathrm{~d} t}-f v=-g \frac{\partial \zeta}{\partial x}+\frac{\tau_{x}}{\rho D} \\ \frac{\mathrm{d} v}{\mathrm{~d} t}+f u=-g \frac{\partial \zeta}{\partial y}+\frac{\tau_{y}}{\rho D}\end{array}\right.$,

where $f$ is the Coriolis constant, $g$ is the gravity, $\zeta$ is the sea surface elevation, $\left(\tau_{x}\right.$ and $\tau_{y}$ ) are the wind stress, $\rho$ is the water density, and $D$ is the mixed layer depth. For the geostrophic current $\left(u_{\mathrm{G}}, v_{\mathrm{G}}\right)$ and Ekman wind-driven currents $\left(u_{\mathrm{E}}, v_{\mathrm{E}}\right)$, we have

$15\left\{\begin{array}{l}-f v_{\mathrm{G}}=-g \frac{\partial \zeta}{\partial x} \\ f u_{\mathrm{G}}=-g \frac{\partial \zeta}{\partial y}\end{array}\right.$,

and

$$
\left\{\begin{array}{l}
-f v_{\mathrm{E}}=\frac{\tau_{x}}{\rho D} \\
f u_{\mathrm{E}}=\frac{\tau_{y}}{\rho D}
\end{array} .\right.
$$

From the geostrophic current relationship (Eq. 5), we have the non-divergent condition,

$$
\left(\frac{\partial u_{G}}{\partial x}+\frac{\partial v_{G}}{\partial y}\right)=0
$$

Surface currents and

upwelling in

Kerguelen Plateau

regions

M. Zhou et al.

Title Page

Abstract

Introduction

Conclusions

Tables

References

Figures

14

4

Back

Full Screen / Esc

Printer-friendly Version

Interactive Discussion 
The wind stress $\left(\tau_{x}\right.$ and $\left.\tau_{y}\right)$ can be estimated by combining Eqs. (4) and (5),

$\left\{\begin{array}{l}\tau_{x}=\rho D\left[\frac{\mathrm{d} u}{\mathrm{~d} t}-f\left(v-v_{\mathrm{G}}\right)\right] \\ \tau_{y}=\rho D\left[\frac{\mathrm{d} v}{\mathrm{~d} t}+f\left(u-u_{\mathrm{G}}\right)\right]\end{array}\right.$

$11,6845-6876,2014$

The wind stress is proportional to wind field, i.e.,

$5\left\{\begin{array}{l}\tau_{x}=C_{\mathrm{D}} u_{\mathrm{W}} \\ \tau_{y}=C_{\mathrm{D}} v_{\mathrm{W}}\end{array}\right.$.

where $\left(u_{\mathrm{W}}, v_{\mathrm{W}}\right)$ are the east and north components of wind, and $C_{\mathrm{D}}$ is the drag coefficient. If we assume the wind field is at the mesoscale so that it is geostrophically balanced, we have

${ }_{10}\left(\frac{\partial \tau_{x}}{\partial x}+\frac{\partial \tau_{y}}{\partial y}\right)=0$

To obtain geostrophic currents, we fit the filtered current data with a streamfunction (Bretherton et al., 1976; Dorland and Zhou, 2007). Because there is no geostrophic streamfunction associated with Ekman wind-driven currents, fitting a geostrophic streamfunction to filtered currents during interpolation will remove ageostrophic components from current measurements and provide geostrophic current estimates.

After computing the geostrophic currents, we combine Eqs. (8) and (10) to compute the non-divergent mesoscale wind stress by fitting a streamfunction to wind stress estimates (Eq. 8). The Ekman divergence can be computed by

${ }_{20} \frac{\partial u_{\mathrm{E}}}{\partial x}+\frac{\partial v_{\mathrm{E}}}{\partial y}=\frac{1}{f \rho D}\left(\frac{\partial \tau_{y}}{\partial x}-\frac{\partial \tau_{x}}{\partial y}\right)$.

Surface currents and

upwelling in

Kerguelen Plateau

regions

M. Zhou et al.

Title Page

Abstract

Introduction

Conclusions

References

Tables

Figures

14

I

4

Back

Close

Full Screen / Esc

Printer-friendly Version

Interactive Discussion 
Using the continuity equation, i.e.,

$\frac{\partial w}{\partial z}=-\left(\frac{\partial u_{\mathrm{E}}}{\partial x}+\frac{\partial v_{\mathrm{E}}}{\partial y}\right)$

and integrating it over the mixed layer depth $(D)$, the upwelling $\left(w_{\mathrm{D}}\right)$ at the bottom of

the mixed layer is equal to

$w_{\mathrm{D}}=\int_{\mathrm{D}}^{0}\left(\frac{\partial u_{\mathrm{E}}}{\partial x}+\frac{\partial v_{\mathrm{E}}}{\partial y}\right) d z$

Surface currents and

upwelling in

Kerguelen Plateau

regions

M. Zhou et al.

where the mixed layer depth is assumed equal to $50 \mathrm{~m}$ in the computation.

Using the technique fitting a streamfunction based on Eqs. (7) and (10) warrants the 10 nondivergent conditions of geostrophic currents and mesoscale wind fields, and gives the best estimates of these current and wind fields. To have better estimates, a 2 day filter is applied first to remove motions with tidal and inertial motion periods, and then the streamfunctions are computed using the technique based on the least-squares fitting (Bretherton et al., 1976; Dorland and Zhou, 2007). These streamfunction-based interpolations could be biased by a lack of spatial and temporal coverage of data in our study area. But if there is a consistent large scale pattern observed repeatedly by drifters, the streamfunction fitting can help us to remove random small-mesoscale variations for a view over the large scale pattern.

\section{Results}

20 The 2 day averaged trajectories of these drifters indicate an eastward mean current north of the Kerguelen Islands representing the ACC (Fig. 2). The 2 day average is determined by the autocovariances computed to understand the nature of mesoscale randomness in drifter motions (Fig. 3). To separate the large trends and mesoscale

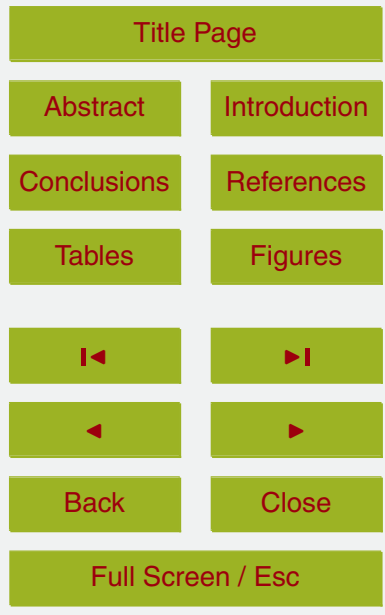

Printer-friendly Version

Interactive Discussion 
variations, a 20 day filter is applied. The high frequency variations less than 20 days contribute more than $70 \%$ of kinetic energy. The first zero crossing of autocovariances is at 2 days, most of which are contributed by tidal currents and inertial motions. To remove these motions, a 2 day filter is applied.

5 Drifters on the Kerguelen Plateau moved northward (Fig. 4), converged into the southeastern slope of the Kerguelen Islands, and exited through 3 pathways: drifter 41419 merged into the shelfbreak current along the shelf slope east of the Kerguelen Islands, joined the confluence between the shelfbreak current and ACC, and flowed along the Gallieni Spur departing from Kerguelen Plateau, drifter 39969 exited east10 ward off the plateau and moved northward into the East Kerguelen Basin, and drifter 41551 moved slowly in the Kerguelen-Heard shelf basin, exited and flowed eastward into the Australian Antarctic Basin. In the East Kerguelen Basin, an array of 5 drifters deployed in an area less than $10 \mathrm{~km}$ moved southwestward for 5 days and then bifurcated (Fig. 5). Regardless circulating northward or southward, all these drifters rejoined 15 at the Gallieni Spur elucidating the strong mesoscale activities in the East Kerguelen Basin and a mean northward drifting of the surface waters.

The mean current field is computed using 4 day ensemble averages as the Lagrangian integral scale is equal to 4 days estimated by 2 times of the first zero crossing (Inoue, 1950; Ogura, 1952). The current field consists of a northward shelfbreak curalong the Gallieni Spur associated with the polar front, and a large scale southward meandering at $75^{\circ} \mathrm{E}$. These currents surround the East Kerguelen Basin with strong eddy activities (Fig. 6).

The diffusivity tensor is computed based on Eqs. (2) and (3) shown in Fig. 7. There are significantly higher on the Kerguelen Islands shelf region than those off the plateau, while $k_{x y}$ and $k_{y x}$ become negative in the shelfbreak current region and positive in the East Kerguelen Basin.

BGD

$11,6845-6876,2014$

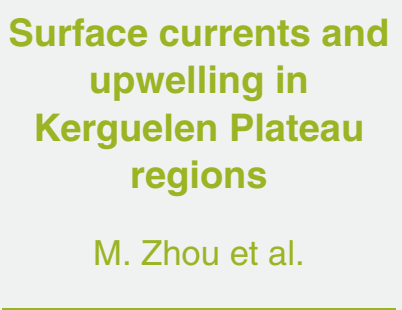

Title Page

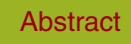

Introduction

Conclusions

Tables

References

Figures

14

4

Back

Full Screen / Esc

Printer-friendly Version

Interactive Discussion 
The acceleration and Coriolis force of a drifter are balanced by the surface gradients and wind stress in Eq. (4), and can be directly computed. Because we cannot separate surface gradients and wind stress in Eq. (4), the sum of surface gradients and wind stress is simply called as the apparent sea surface gradients for the convenience. To 5 compute the accelerations and Coriolis force, the drifter data were binned in to boxes of $1 / 8^{\circ}$ in the latitude and $1 / 4^{\circ}$ in the longitude, and then the mean currents and sums of acceleration and Coriolis force are computed (Fig. 8). The strongest pressure gradients were in the eastern slope of the Kerguelen Plateau and Gallieni Spur areas associated with the strong shelfbreak current and Crozet-Kerguelen Confluence. The currents and 10 the apparent sea surface gradients are mostly in perpendicular indicating the primary geostrophic nature of these currents.

The nondivergent mean currents computed based on Eq. (7) and the streamfunction fitting are shown in Fig. 9. The results confirm that a shelfbreak current flows along the southern and eastern shelf slopes of the Kerguelen Islands. The strong current associated with the Crozet-Kerguelen Confluence exits from the Gallieni Spur, and then turns southward at $75^{\circ} \mathrm{E}$. Along the eastern shelf slope of the Kerguelen Islands, the current converges while in the East Kerguelen Basin, the current forms a pair of a divergent center at $48.5^{\circ} \mathrm{S}$ and $72^{\circ} \mathrm{E}$, and a convergent center at $48.5^{\circ} \mathrm{S}$ and $73^{\circ} \mathrm{E}$ (Fig. 9). The areal mean upwelling velocities on the plateau and in the deep basin circled by the red and gray enclosed curves are computed approximately $3.3 \mathrm{md}^{-1}$ and $3.9 \mathrm{md}^{-1}$, respectively. Overall, the mean and standard deviation of vertical velocities driven by wind stress curl averaged in these two circled regions up to $3.2 \pm 7.4 \mathrm{md}^{-1}$. The waters in the Kerguelen-Heard shelf basin exit eastward in the area around $49.5^{\circ} \mathrm{S}$ and $72.5^{\circ} \mathrm{E}$ and then northward into the East Kerguelen Basin or northeastward into the

Australian Antarctic Basin. The mean currents are weak but persistent with upwelling along their paths.

The upwelling and downwelling regions can be seen from the domes and depressions of isopycnals along the west-east transect (Fig. 10): a depression at the shelf slope around $71^{\circ} \mathrm{E}$, a dome around $72^{\circ} \mathrm{E}$, a depression around $72.75-73^{\circ} \mathrm{E}$, a dome
BGD

$11,6845-6876,2014$

Surface currents and

upwelling in

Kerguelen Plateau

regions

M. Zhou et al.

Title Page

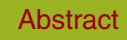

Introduction

Conclusions

Tables

References

Figures

14

4

Back

Full Screen / Esc

Printer-friendly Version

Interactive Discussion 
around $73.5^{\circ} \mathrm{E}$, and a depression around $74-75^{\circ} \mathrm{E}$. These domes and depressions are remarkably consistent with those estimated upwelling and downwelling areas in Fig. 9. At the eastern end of this transect, the warm water mass was found in the depth which might be associated with the waters north of the polar front.

5 The meteorological forcing on deep waters can be examined from the wind stress curl, and in turn the upwelling and downwelling. The mean wind stress curl in the October and November period from QuikSCAT data show that the curls on the Kerguelen Plateau are primarily positive and the curls in the East Kerguelen Basin form a large negative region (Fig. 11), that corresponds to an Ekman downwelling and upwelling on and off the plateau, respectively.

\section{Discussions}

\subsection{Mean currents and residence times}

The drifter trajectories revealed the northeastward movement of the surface waters on the Kerguelen Plateau (Figs. 2, 8 and 9). Drifter 41551 deployed at Station A2 recircu15 lated around the station nearly 20 days before it moved slowly northward (Fig. 4). It took approximately 60 days traveling $100 \mathrm{~km}$ to the southeastern shelf slope of the Kerguelen Islands equivalent to a northward translation speed of $2 \mathrm{~cm} \mathrm{~s}^{-1}$. The southeastern shelf slope region of the Kerguelen Islands is a convergent area of the surface waters in the Kerguelen-Heard shelf basin where the drifters accelerated to $24 \mathrm{~cm} \mathrm{~s}^{-1}$ joining the shelfbreak current along the slope, or crossed the slope into the East Kerguelen Basin at a speed of $12 \mathrm{~cm} \mathrm{~s}^{-1}$. The shelf break current continued onto the Gallieni Spur and accelerated up to $40-50 \mathrm{~cm} \mathrm{~s}^{-1}$ joining the Crozet-Kerguelen Confluence. The western boundary current originated from the Fawn Trough Current was not clear in this eastern slope region off the Kerguelen-Heard shelf basin (McCartney and Donohue, 2007). If the waters on the Kerguelen Plateau are enriched with DFe, both the shelfbreak and cross-slope currents carrying the DFe enriched waters can fertilize downstream.
BGD

$11,6845-6876,2014$

Surface currents and upwelling in Kerguelen Plateau

regions

M. Zhou et al.

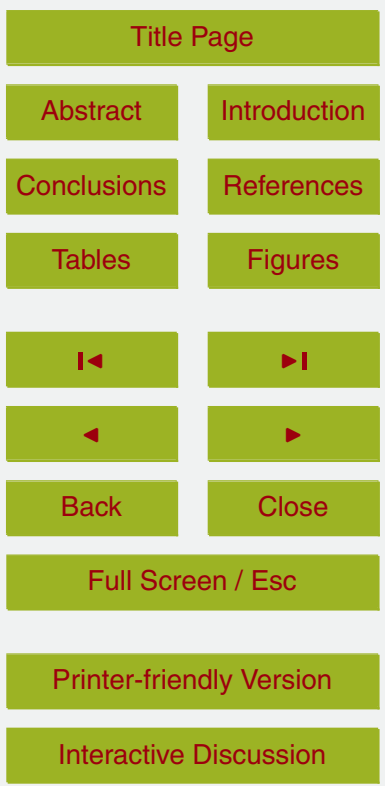


Some shelf waters on the Kerguelen Plateau exited into the East Kerguelen Basin and slowly moved northward and eastward at approximately $6 \mathrm{cms}^{-1}$ with strong mesoscale eddies and meanders. These surface waters resided in the East Kerguelen Basin approximately 20-30 days before their departures. Thus, the surface waters in 5 the Kerguelen-Heard Shelf basin have the longest residence time of 30-70 days, those in the East Kerguelen Basin have the intermediate residence time of 20-30 days, and those in the shelfbreak current have the shortest residence time.

The Kerguelen Plateau lies in the westerly wind region which produces a northward movement in the upper mixed layer in general. The drifter trajectories on the Kerguelen 10 Plateau are consistent with the northward wind driven current (Fig. 8). Considering that the Kerguelen Plateau is approximately $300 \mathrm{~km}$ wide and the shelf slope approximately only $20 \mathrm{~km}$ wide, if all the northward sluggish current of $2 \mathrm{cms}^{-1}$ on the plateau converges into a narrow slope, it will produce a current of $30 \mathrm{~cm}^{-1}$. Only part of northward sluggish currents on the Plateau converges into the strong current on the slope, and 15 others crossed the slope into the East Kerguelen Basin.

The meridional transport $(V)$ in the deep water can be estimated from the wind stress curl based on the Sverdrup theory, that is,

$\beta V=\frac{1}{\rho_{\mathrm{s}}}\left(\frac{\partial \tau_{y}}{\partial x}-\frac{\partial \tau_{x}}{\partial y}\right)$.

20 where $\beta$ is equal to $\mathrm{d} f / \mathrm{d} y$ and $\rho_{\mathrm{s}}$ is the seawater density in the surface layer. On the Kerguelen Plateau the wind stress curl is positive with a mean of $0.84 \times 10^{-4} \mathrm{Nm}^{-3}$ in October and November (O'Neill et al., 2005; Risien and Chelton, 2008), the meridional transport is equal to $5.6 \mathrm{~m}^{2} \mathrm{~s}^{-1}$. Assuming the longitudinal width of the plateau equal to $300 \mathrm{~km}$ wide, the northward Sverdrup transport is approximately $1.7 \mathrm{~Sv}$. Because the depth of Sverdrup transport is limited by the buoyancy of these downwelled surface waters, this transport may not be limited by deep depth and the slope between the shelf basin and the deep East Kerguelen Basin. This transport is probably a significant contribution to the off-plateau transport.
BGD

$11,6845-6876,2014$

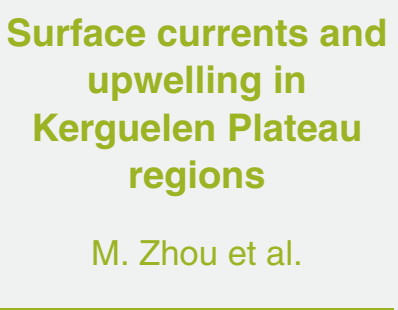

Title Page

Abstract Introduction

Conclusions

Tables References Figures

14

4

Back

Close

Full Screen / Esc

Printer-friendly Version

Interactive Discussion 


\subsection{Stability of currents and horizontal mixing}

The shelfbreak current is typically hydrodynamically stable (Zhou et al., 2006). Considering that the change of mesoscale eddy kinetic energy (EKE) is proportional to the work done by Reynolds stress, i.e.,

${ }_{5} \frac{\mathrm{dEKE}}{\mathrm{d} t} \sim-\left(\overline{u^{\prime} u^{\prime}} \frac{\partial\langle u\rangle}{\partial x}+\overline{u^{\prime} v^{\prime}} \frac{\partial\langle u\rangle}{\partial y}+\overline{v^{\prime} u^{\prime}} \frac{\partial\langle v\rangle}{\partial x}-\overline{v^{\prime} v^{\prime}} \frac{\partial\langle v\rangle}{\partial y}\right)$,

where $\langle u\rangle$ and $\langle u\rangle$ represent the mean, and $u^{\prime}, v^{\prime}$ and $p^{\prime}$ represent the mesoscale fluctuations. As the Reynolds stress can be written as the product of eddy diffusivity and mean current shear, we have

${ }_{10} \frac{\mathrm{dEKE}}{\mathrm{d} t} \sim \kappa_{x x}^{\infty}\left(\frac{\partial\langle u\rangle}{\partial x}\right)^{2}+k_{x y}^{\infty}\left(\frac{\partial\langle u\rangle}{\partial y}\right)^{2}+k_{y x}^{\infty}\left(\frac{\partial\langle v\rangle}{\partial x}\right)^{2}+\kappa_{y y}^{\infty}\left(\frac{\partial\langle v\rangle}{\partial y}\right)^{2}$.

In general, Reynolds stress transfers kinetic energy from larger scale mean currents to random smaller scale fluctuations. High values of $k_{x x}^{\infty}$ and $k_{y y}^{\infty}$ are found on the shelf slope presuming that strong shelfbreak currents fluctuate leading to an increase 15 in EKE. Relative low values of $k_{x x}^{\infty}$ and $\kappa_{y y}^{\infty}$ are found in the East Kerguelen Basin where there is a lack of strong mean currents. The patterns of $k_{x y}^{\infty}$ and $\kappa_{y x}^{\infty}$ are very different from those of $\kappa_{x x}^{\infty}$ and $k_{y y}^{\infty}$. Negative values of $\kappa_{x y}^{\infty}$ and $k_{y x}^{\infty}$ are found in the shelf slope region implying that stable shelfbreak currents are capable to absorb kinetic energy from mesoscale eddies for increasing the strength of mean currents. In the East 20 Kerguelen Basin, high positive values of $k_{x y}^{\infty}$ and $k_{y x}^{\infty}$ are found where the Reynolds stress transfers kinetic energy from mean current shears to EKE. The mean value of $k_{x y}^{\infty}$ and $\kappa_{y x}^{\infty}$ is on the order of magnitude approximately $5 \times 10^{7} \mathrm{~cm}^{2} \mathrm{~s}^{-1}$ and the horizontal scale $(L)$ of the East Kerguelen Basin is approximately $100 \mathrm{~km}$. The mixing time scale crossing the East Kerguelen Basin can be estimated as

${ }_{25} T_{\mathrm{M}} \sim \frac{L^{2}}{\left\langle\kappa_{x y}\right\rangle} \approx 20$ days.

BGD

$11,6845-6876,2014$

Surface currents and

upwelling in

Kerguelen Plateau

regions

M. Zhou et al.

Title Page

Abstract

Introduction

Conclusions

Tables

References

Figures

14

4

Back

Close

Full Screen / Esc

Printer-friendly Version

Interactive Discussion 
This value is equivalent to the mean advection time scale of 20-30 days in the East Kerguelen Basin from the trajectories of drifters 39969 and 41551 which moved northward or eastward with a mean current of approximately $6 \mathrm{cms}^{-1}$. The transports from the mean current and horizontal mesoscale eddy mixing are on the same order of 5 magnitude in the East Kerguelen Basin.

\subsection{Upwelling and cross-slope transport}

The currents are primarily geostrophically balanced between the apparent sea surface slope and Coriolis force (Fig. 8). The accelerations are small, that is, the Rossby numbers are generally small. These 48 drifters elucidate a persistent cyclonic meander around the East Kerguelen Basin. The meander starts from the southeastern shelf slope of the Kerguelen Islands as the shelfbreak current, flows northward and then eastward along the shelf slope, exits into the Australian Antarctic Basin along the Gallieni Spur, and circulates southward around $75^{\circ} \mathrm{E}$. This large scale meander around the East Kerguelen Basin has been observed and discussed in several studies (McCartney and Donohue, 2007; Park et al., 2008b). To accommodate this large scale geostrophically balanced meander, the sea surface height must be depressed in the East Kerguelen Basin. This sea surface gradient can only be maintained by a cyclonic wind, or a negative wind stress curl region centered at the East Kerguelen Basin which has been observed from QuikSCAT (Fig. 11) (O'Neill et al., 2005; Risien and Chelton, 2008; Cambra et al., 2014). This negative wind stress curl will produce an Ekman divergence in the East Kerguelen Basin, and in turn produce an upwelling which is implied from the doming isopycnals shown in Fig. 10. The mean wind stress curl in this East Kerguelen Basin is approximately $-0.82 \times 10^{-4} \mathrm{Nm}^{-3}$ in October and November. The upwelling driven by this wind stress curl is only $6.4 \mathrm{~cm} \mathrm{~d}^{-1}$, probably due to the smoothened wind

data with a $70 \mathrm{~km}$ filter. The upwelling fluxes computed from drifter data have much high spatial variability and the areal means of upwelling in the Kerguelen Plateau and East Kerguelen Basin regions are approximately $3.3 \mathrm{md}^{-1}$ and $3.9 \mathrm{md}^{-1}$, respectively,
BGD

$11,6845-6876,2014$

Surface currents and upwelling in Kerguelen Plateau

regions

M. Zhou et al.

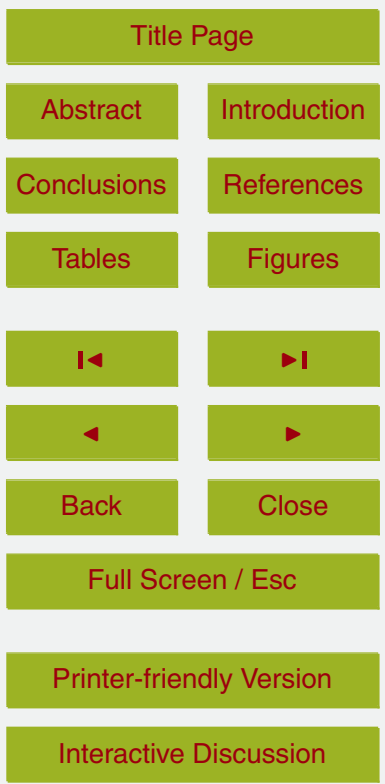


and in the combined plateau and deep basin region, the mean and standard deviation of vertical velocities averaged from drifter data are up to $3.2 \pm 7.4 \mathrm{md}^{-1}$, respectively.

The surface waters in the Kerguelen-Heard shelf basin were transported northward off the Kerguelen Plateau. Most of those exiting drifters continued to move northward 5 while a few of them directly moved eastward (Figs. 2 and 9). Considering the surface current crossing the slope approximately equal to $10 \mathrm{~cm} \mathrm{~s}^{-1}$ over a section of $100 \mathrm{~km}$, the volume transport off the plateau in the upper $50 \mathrm{~m}$ specified based on surface drifters will be approximately $0.5 \mathrm{~Sv}$. In the depth below the mixed layer, there is a northward Sverdrup transport of $1.7 \mathrm{~Sv}$ taking DFe rich deep waters off the Kergue10 len Plateau into the East Kerguelen Basin. A total of $2.2 \mathrm{~Sv}$ of waters on the plateau is transported into the East Kerguelen Basin.

The upwelling estimates from drifter data are significant higher than that of oversmoothened wind stress curl. The upwelling fluxes in the circled areas on the Kerguelen Plateau and in East Kerguelen Basin are approximately 0.7 and $1.1 \mathrm{~Sv}$, respectively. 15 Thus, the horizontal and vertical volume fluxes into the surface waters in the East Kerguelen Basin are equivalent, 0.5 and $1.1 \mathrm{~Sv}$, respectively, a total of $1.6 \mathrm{~Sv}$. These volume fluxes may play a significant role in transporting biogeochemical elements and affecting their balances in off plateau deep basins.

\section{Conclusions}

20 Drifters have revealed a detailed circulation pattern in the Kerguelen Plateau and its vicinity. Approximate $0.5 \mathrm{~Sv}$ of the surface water and $1.7 \mathrm{~Sv}$ of the deep water in the plateau drifted northeastward driven by the westerly wind and Ekman pumping due to the positive wind stress curl, respectively. Both the surface and deep waters converged at the southeastern shelf slope of the Kerguelen Islands during our study period. Some waters were transported off the plateau into the East Kerguelen Basin. The shelfbreak current turned eastward along the Gallieni Spur, and then recirculated southward after 
the current exited from the ridge. This large scale cyclonic meander marked the boundaries of an Ekman divergent zone within the East Kerguelen Basin with an upwelling of approximately $1.1 \mathrm{~Sv}$. This cyclonic meander is stable and strengthened by absorbing kinetic energy from mesoscale horizontal shears. Strong horizontal mixing was found in 5 the East Kerguelen Basin off the plateau. The surface and deep waters on the Kerguelen Plateau were transported off the plateau into the East Kerguelen Basin by either a mean crossing slope current or mesoscale horizontal mixing. Considering that the deep water on the plateau is originated from the DFe deficient ACC deep water from the west of the Kerguelen Plateau, it was enriched with DFe through remineralization 10 and contacting with sediments on the plateau, and transported into the East Kerguelen Basin by either shelfbreak current, crossing slope current or mesoscale mixing. The persistent upwelling in the East Kerguelen Basin may play the critical role in transporting these deep DFe rich waters into the surface waters.

Acknowledgements. This project was supported by the French Agency of National Research 15 grant (ANR-09-CEXC-006-01) to M. Zhou and F. Carlotti, and the US National Science Foundation (ANT-0 948 378). MZ would like to acknowledge the support from US NOAA-AOML-DAC for their kind support by providing 48 SVP drifters and sending daily drifter data during and after the cruise. This manuscript is a tribute to P. P. Niiler for his hearty support to unconventional and interdisciplinary marine sciences conducted in this Southern Indian Ocean project.

\section{References}

Amos, A. F.: A decade of oceanographic variability in summertime near Elephant Island, Antarctica, J. Geophys. Res., 106, 22401-22423, 2001.

Blain, S., Quéguiner, B., Armand, L., Belviso, S., Bombled, B., Bopp, L., Bowie, A., Brunet, C., Brussaard, K., Carlotti, F., Christaki, U., Corbière, A., Durand, I., Ebersbach, F., Fuda, J. L., C., Laan, P., Lefèvre, D., Lomonaco, C., Malits, A., Mosseri, J., Obernosterer, I., Park, Y. H., Picheral, M., Pondaven, P., Remenyi, T., Sandroni, V., Sarthou, G., Savoye, N., Scouarnec, L., Souhault, M., Thuillers, D., Timmermans, K. R., Trull, T., Uitz, J., Van-Beek, P., Veldhuis, M.

BGD

11, 6845-6876, 2014

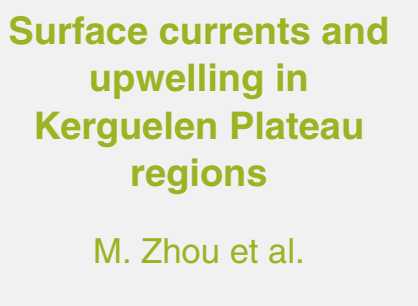

Title Page

Abstract Introduction

Conclusions

Tables

References

Figures

14

4

Back

Close

Full Screen / Esc

Printer-friendly Version

Interactive Discussion $\rightarrow$

\section{sc}


J. W., Vincent, D., Viollier, E., Vong, L., and Wagener, T.: Effect of natural iron fertilization on carbon sequestration in the Southern Ocean, Nature, 446, doi:10.1038/nature05700, 2007.

Cambra, R., Carranza, M., Gille, S. T., and Morrow, R.: Wind-induced Upwelling in the Kerguelen Plateau Region, Biogeosciences, in preparation, 2014.

5 Charette, M. A., Gonneea, M. E., Morris, P. J., Statham, P., Fones, G., Planquette, H., Salter, I., and Garabato, A. C. N.: Radium isotopes as tracers of iron sources fueling a Southern Ocean phytoplankton bloom, Deep-Sea Res. Pt. II, 54, 1989-1998, 2007.

Coale, K. H., Johnson, K. S., Chavez, F. P., Buesseler, K. O., Barber, R. T., Brzezinski, M. A., Cochlan, W. P., Millero, F. J., Falkowski, P. G., Bauer, J. E., Wanninkhof, R. H., Kudela, R. M., Altabet, M. A., Hales, B. E., Takahashi, T., Landry, M. R., Bidigare, R. R., Wang, X., Chase, Z., Strutton, P. G., Friederich, G. E., Gorbunov, M. Y., Lance, V. P., Hilting, A. K., Hiscock, M. R., Demarest, M., Hiscock, W. T., Sullivan, K. F., Tanner, S. J., Gordon, R. M., Hunter, C. N., Elrod, V. A., Fitzwater, S. E., Jones, J. L., Tozzi, S., Koblizek, M., Roberts, A. E., Herndon, J., Brewster, J., Ladizinsky, N., Smith, G., Cooper, D., Timothy, D., Brown, S. L., Selph, K. E., Sheridan, C. C., Twining, B. S., and Johnson, Z. I.: Southern ocean iron enrichment experiment: carbon cycling in high- and low-Si waters, Science, 304, 408-414, 2004.

Davis, R. E.: Observing the general circulation with floats, Deep-Sea Res., 38, S531-S571, 1991.

Davis, R. E.: Intermediate-depth circulation of the Indian and South Pacific Oceans measured by autonomous floats, J. Phys. Oceanogr., 35, 683-707, 2005.

Dulaiova, H., Ardelan, M. V., Henderson, P. B., and Charette, M. A.: Shelf-derived iron inputs drive biological productivity in the southern Drake Passage. Global Biogeochem. Cy., 23, GB4014, doi:10.1029/2008GB003406, 2009.

Frants, M., Gille, S. T., Hatta, M., Hiscock, W. T., Kahru, M., Measures, C. I., and Zhou, M.: Analysis of horizontal and vertical processes contributing to natural iron supply in the mixed layer in southern Drake Passage, Deep-Sea Res. Pt. II, 90, 69-76, 2013.

Gille, S. T.: Float observations of the Southern Ocean, Part I: Estimating mean fields, bottom velocities, and topographic steering, J. Phys. Oceanogr., 33, 1167-1181, 2003.

30 Hansen, D. V. and Poulain, P. M.: Quality control and interpolations of WOCE-TOGA drifter data, J. Atmos. Ocean. Technol., 13, 900-909, 1996.
BGD

$11,6845-6876,2014$

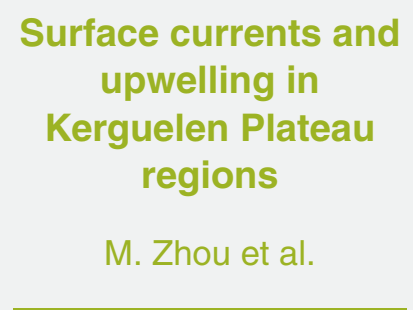

Title Page

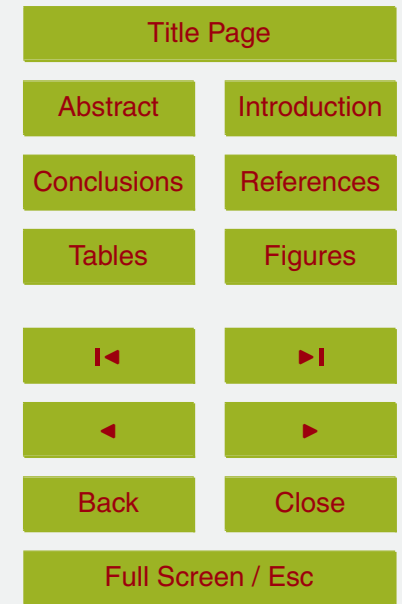

Printer-friendly Version

Interactive Discussion 
Hatta, M., Measures, C. I., Selph, K. E., Zhou, M., Yang, J. J., and Hiscock, W. T.: Iron fluxes from the shelf regions near the South Shetland Islands in the Drake Passage during the austral-winter 2006, Deep-Sea Res. Pt. II, 90, 89-101, 2013.

Martin, J. H., Gordon, R. M., and Fitzwater, S. E.: Iron in Antarctic waters, Nature, 345, 156158, 1990.

McCartney, M. S. and Donohue, K. A.: A deep cyclonic gyre in the Australian-Antarctic Basin, Prog. Oceanogr., 75, 675-750, 2007.

Measures, C. I., Brown, M. T., Selph, K. E., Apprill, A., and Zhou, M.: The Influence of Shelf Processes in Delivering Dissolved Iron to the HNLC waters of the Drake Passage, Antarctica,

10 Deep-Sea Res. Pt. II, 90, 77-88, 2013.

Monin, A. S. and Yaglom, A. M.: Statistical Fluid Mechanics: Mechanics of Turbulence, MIT Press, Cambridge, Massachusetts, and London, England, 769 pp., 1971.

Niiler, P. P., Davis, R. E., and White, H. J.: Water-following characteristics of a mixed layer drifter, Deep-Sea Res., 34, 1867-1881, 1987.

Niiler, P. P., Sybrandy, A. S., Bi, K., Poulain, P. M., and Bitterman, D. M.: Measurements of the water-following capability of Holey-sock and TRISTAR drifters, Deep-Sea Res., 42, 19511964, 1995.

Ogura, Y.: The theory of turbulent diffusion in the atmosphere, J. Meteor. Soc. Jpn., 30, 23-28, 1952.

20 O'Neill, L. W., Chelton, D. B., Esbensen, S. K., and Wentz, F. J.: High-resolution satellite measurements of the atmospheric boundary layer response to SST variations along the Agulhas Return Current, J. Climate, 18, 2706-2723, 2005.

Orsi, A. H. and Wiederwohl, C. L.: A recount of Ross Sea waters, Deep-Sea Res. Pt. II 56, 778-795, 2009.

Park, Y.-H., Pollard, R. T., Read, J. F., and Leboucher, V.: A quasi-synoptic view of the frontal circulation in the Crozet Basin during the Antares4 cruise, Deep-Sea Res. Pt. II, 49, 18231842, 2002.

Park, Y.-H., Fuda, J.-L., Durand, I., and Naveira Garabato, A. C.: Internal tides and vertical mixing over the Kerguelen Plateau, Deep-Sea Res. Pt. II, 55, 582-593, 2008a.

30 Park, Y.-H., Roquet, F., Durand, I., and Fuda, J.-L.: Large-scale circulation over and around the Northern Kerguelen Plateau, Deep-Sea Res. Pt. II, 55, 566-581, 2008b.

Pedlosky, J.: Geophysical Fluid Dynamics, Springer-Verlag, New York, 624 pp., 1987. 
Pollard, R. T., Salter, I., Sanders, R. J., Lucas, M. I., Moore, C. M., Mills, R. A., Statham, P. J., Allen, J. T., Baker, A. R., Bakker, D. C. E., Charette, M. A., Fielding, S., Fones, G. R., French, M., Hickman, A. E., Holland, R. J., Hughes, J. A., Jickells, T. D., Lampitt, R. S., Morris, P. J., Nedelec, F. H., Nielsdottir, M., Planquette, H., Popova, E. E., Poulton, A. J., Read, J. F., Seeyave, S., Smith, T., Stinchcombe, M., Taylor, S., Thomalla, S. J., Venables, H. J., Williamson, R., and Zubkov, M. V.: Southern Ocean deep-water carbon export enhanced by natural iron fertilization, Nature, 457, 577-580, doi:10.1038/nature07716, 2009.

Poulain, P. and Niiler, P. P.: Statistical analysis of the surface circulation in the California Current system using satellite-tracked drifters, J. Phys. Oceanogr., 19, 1588-1603, 1989.

10 Risien, C. M. and Chelton, D. B.: A global climatology of surface wind and wind stress fields from eight years of QuikSCAT scatterometer data, J. Phys. Oceanogr., 38, 2379-2413, 2008.

Sedwick, P. N., DiTullio, G. R., and Mackey, D. J.: Iron and manganese in the Ross Sea, Antarctica: seasonal iron limitation in Antarctic shelf waters, J. Geophys. Res.-Oceans, 105, $11321-$ 11336, 2000.

Smith Jr., W. O., Sedwick, P. N., Arrigo, K. R., Ainley, D. G., and Orsi, A. H.: The Ross Sea in a sea of change, Oceanogr., 25, 90-103, 2012.

Sybrandy, A. L. and Niiler, P. P.: WOCE/TOGA Lagrangian drifter construction manual, SIO Reference 91/6, Scripps Inst. Oceanogr., Univ. Cali., San Diego, 1991.

Zhou, M., Paduan, J., and Niiler, P. P.: The surface currents in the Canary Basin from drifter observations, J. Geophys. Res., 105, 21893-21910, 2000.

Zhou, M., Niiler, P. P., Zhu, Y., and Dorland, R. D.: The western boundary current in the Bransfield Strait, Antarctica, Deep-Sea Res. Pt. I, 53, 1244-1252, 2006.

Zhou, M., Zhu, Y., Dorland, R. D., and Measures, C. I.: Dynamics of the current system in the southern Drake Passage, Deep-Sea Res. Pt. I, 57, 1039-1048, 2010.

Surface currents and

upwelling in

Kerguelen Plateau

regions

M. Zhou et al.

Title Page

Abstract

Conclusions

Tables

14

4

Back

Full Screen / Esc

Printer-friendly Version

Interactive Discussion 
Table 1. IDs, times and locations of 48 WOCE SVP drifters deployed.

BGD

\begin{tabular}{|c|c|c|c|c|c|}
\hline ID & Date/time (UTC) & Latitı & e (S) & & titude $(E)$ \\
\hline 41338 & 15 Oct 2011 06:55 & -46 & 4.19 & 51 & 56.82 \\
\hline 41323 & 17 Oct 2011 12:01 & -50 & 7.42 & 65 & 0.37 \\
\hline 41346 & 17 Oct 2011 15:02 & -50 & 24.68 & 65 & 51.09 \\
\hline 41418 & 17 Oct 2011 17:35 & -50 & 41.71 & 66 & 41.41 \\
\hline 41419 & 18 Oct 2011 02:33 & -50 & 40.68 & 68 & 27.91 \\
\hline 41417 & 18 Oct 2011 07:29 & -50 & 39.39 & 70 & 12.64 \\
\hline 41551 & 18 Oct 2011 12:35 & -50 & 37.88 & 72 & 2.64 \\
\hline 41549 & 18 Oct 2011 19:46 & -50 & 11.07 & 71 & 22.25 \\
\hline 41562 & 18 Oct $201121: 51$ & -50 & 0.23 & 71 & 5.19 \\
\hline 41559 & 19 Oct 2011 00:05 & -49 & 48.15 & 70 & 46.22 \\
\hline 41561 & 19 Oct 2011 01:29 & -49 & 38.28 & 70 & 30.74 \\
\hline 39969 & 21 Oct 2011 05:40 & -50 & 11.96 & 72 & 8.90 \\
\hline 41560 & 21 Oct 2011 10:06 & -49 & 48.23 & 72 & 12.89 \\
\hline 40676 & 21 Oct 2011 12:12 & -49 & 36.97 & 72 & 13.28 \\
\hline 41232 & 21 Oct 2011 16:38 & -49 & 28.92 & 72 & 15.46 \\
\hline 40686 & 21 Oct 2011 18:41 & -49 & 16.98 & 72 & 15.78 \\
\hline 41235 & 21 Oct $201120: 15$ & -49 & 9.97 & 72 & 17.02 \\
\hline 41109 & 22 Oct 2011 00:55 & -48 & 57.32 & 72 & 17.50 \\
\hline 92995 & 22 Oct 2011 09:37 & -48 & 43.63 & 72 & 16.25 \\
\hline 92996 & 22 Oct 2011 10:02 & -48 & 40.32 & 72 & 15.64 \\
\hline 93022 & 22 Oct 2011 10:46 & -48 & 35.22 & 72 & 14.16 \\
\hline 93021 & 22 Oct 2011 13:39 & -48 & 28.95 & 72 & 12.59 \\
\hline 93020 & 22 Oct 2011 19:22 & -48 & 10.21 & 72 & 4.18 \\
\hline 81840 & 23 Oct 2011 00:24 & -47 & 58.56 & 71 & 58.85 \\
\hline 93019 & 23 Oct 2011 09:04 & -47 & 19.90 & 71 & 42.07 \\
\hline 81839 & 23 Oct 2011 15:50 & -46 & 50.89 & 71 & 30.79 \\
\hline 81838 & 24 Oct 2011 05:28 & -48 & 48.09 & 72 & 10.27 \\
\hline 81836 & 24 Oct 2011 06:16 & -48 & 48.76 & 71 & 56.4 \\
\hline 81835 & 24 Oct 2011 06:40 & -48 & 52.94 & 71 & 51.67 \\
\hline 81837 & 28 Oct 2011 11:21 & -48 & 25.63 & 72 & 8.06 \\
\hline 37656 & 28 Oct 2011 11:51 & -48 & 25.83 & 72 & 16.24 \\
\hline 37640 & 28 Oct 2011 12:15 & -48 & 29.92 & 72 & 15.83 \\
\hline 37660 & 28 Oct 2011 12:50 & -48 & 30.50 & 72 & 8.2 \\
\hline 37651 & 28 Oct 2011 13:40 & -48 & 27.9 & 72 & 12.32 \\
\hline 41797 & 1 Nov 2011 12:40 & -48 & 29.18 & 72 & 32.99 \\
\hline 41802 & 1 Nov 2011 13:10 & -48 & 28.03 & 72 & 47.43 \\
\hline 41796 & 1 Nov 2011 20:41 & -48 & 27.99 & 73 & 6.74 \\
\hline 37543 & 2 Nov 2011 03:11 & -48 & 27.987 & 73 & 22.87 \\
\hline 41800 & 2 Nov 2011 18:40 & -48 & 28.32 & 74 & 59.93 \\
\hline 41798 & 8 Nov 2011 05:50 & -48 & 36.48 & 73 & 50.45 \\
\hline 41795 & 8 Nov 2011 05:51 & -48 & 36.64 & 73 & 50.2 \\
\hline 41784 & 8 Nov 2011 09:14 & -48 & 57.01 & 73 & 19.85 \\
\hline 41783 & 8 Nov 2011 11:15 & -49 & 9.77 & 73 & 0.73 \\
\hline 41794 & 8 Nov 2011 13:24 & -49 & 25.60 & 72 & 36.95 \\
\hline 41786 & 12 Nov 2011 10:10 & -48 & 45.90 & 71 & 25.49 \\
\hline 41785 & 12 Nov 2011 10:15 & -48 & 45.90 & 71 & 25.49 \\
\hline 41787 & 15 Nov 2011 13:49 & -50 & 18.57 & 72 & 0.82 \\
\hline 37649 & 17 Nov 2011 11:54 & -50 & 38.51 & 72 & 3.781 \\
\hline
\end{tabular}

$11,6845-6876,2014$

Surface currents and

upwelling in

Kerguelen Plateau

regions

M. Zhou et al.

Title Page

Abstract

Introduction

Conclusions

References

Tables

Figures

14

।

Back

Close

Full Screen / Esc

Printer-friendly Version

Interactive Discussion

\section{5}




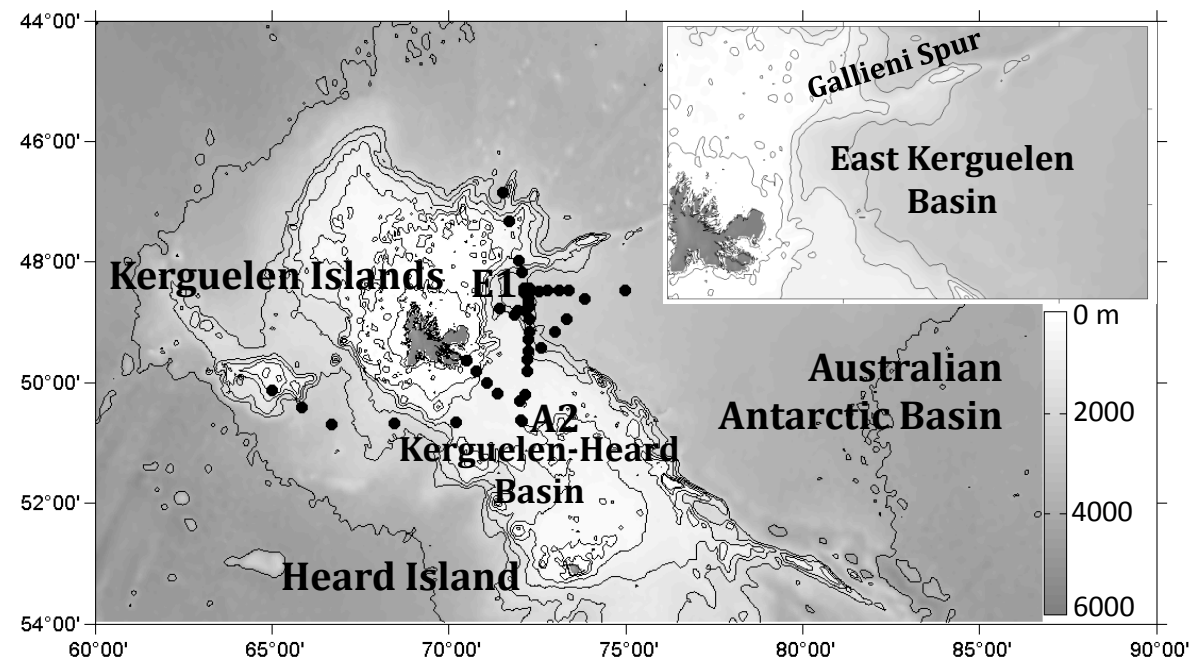

Fig. 1. Bathymetry in the Kerguelen Islands vicinity. False gray colors represent bottom depths; depth contours are 100,500,1000, 2000, 4000 and $6000 \mathrm{~m}$; and black dots are deployments of SVP drifters. The inserted figure shows the enlarged study area. The name of the East Kerguelen Basin is made only for the discussion.
BGD

11, 6845-6876, 2014

Surface currents and upwelling in

Kerguelen Plateau regions

M. Zhou et al.

\section{Title Page}

\section{Abstract}

Introduction

Conclusions

References

Tables

Figures

14

-I

Back

Close

\section{Full Screen / Esc}

Printer-friendly Version

Interactive Discussion 


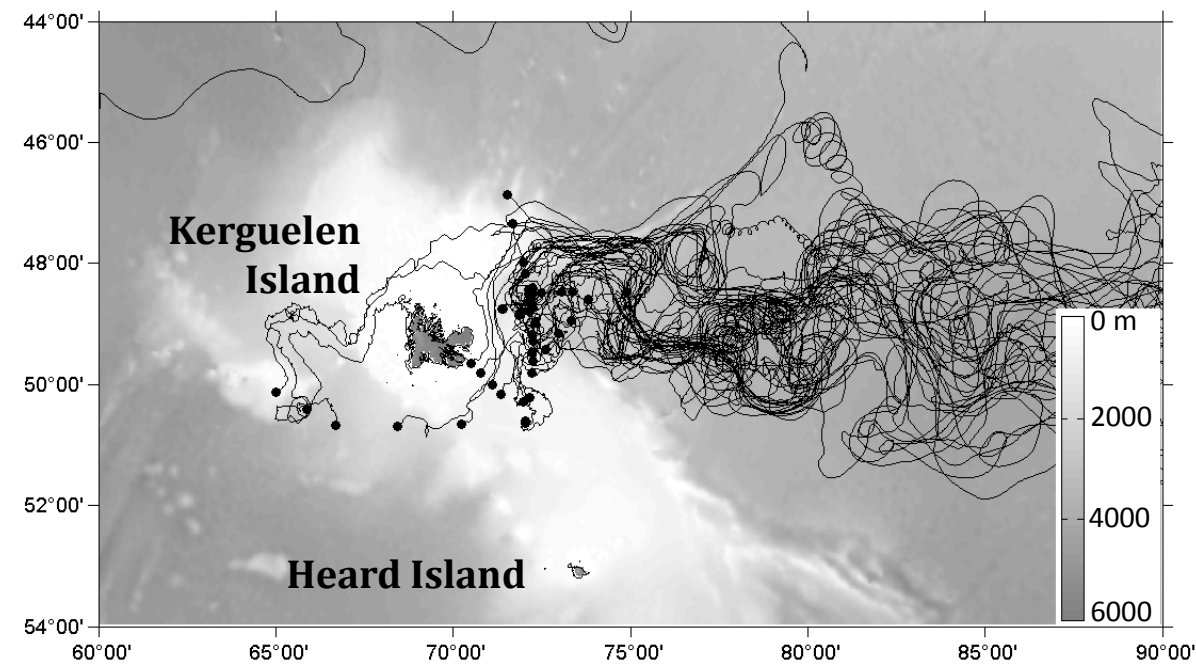

Fig. 2. Trajectories of SVP drifters deployed during the KEOPS II cruise. Black dots are deployment locations, and black lines are drifter trajectories.

\section{BGD}

11, 6845-6876, 2014

Surface currents and upwelling in

Kerguelen Plateau regions

\section{Zhou et al.}

\section{Title Page}

\section{Abstract}

Introduction

Conclusions

References

Tables

Figures

14

$\rightarrow$ I

Back

Close

\section{Full Screen / Esc}

Printer-friendly Version

Interactive Discussion 


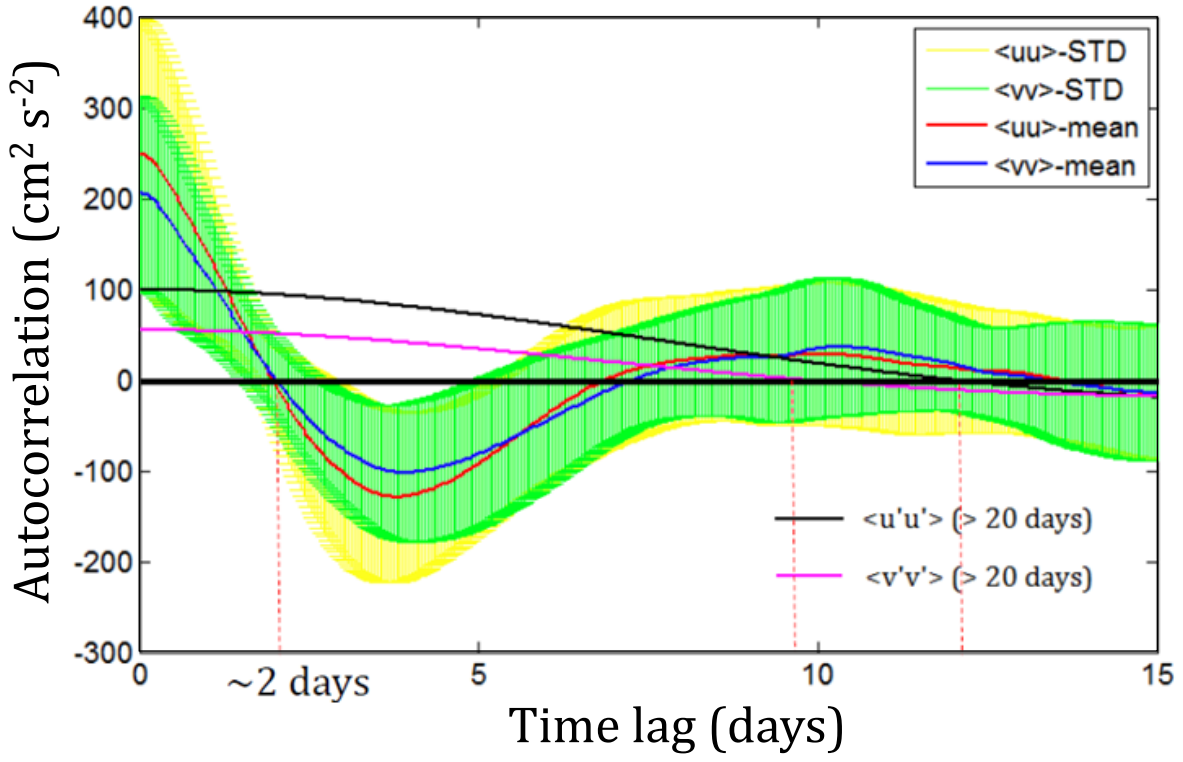

Fig. 3. Autocovariance functions and standard deviations. Red and blue solid lines are $u$ and $v$ autocorrelations after a 20 day high-pass filter is applied, respectively, and yellow and green bands are standard deviations of $u$ and $v$ autocovariances, respectively. Black and purple lines are the $u$ and $v$ autocovariances after a 20 day low-pass filter is applied, respectively.

\section{BGD}

$11,6845-6876,2014$

Surface currents and upwelling in

Kerguelen Plateau

regions

M. Zhou et al.

\section{Title Page}

Abstract

Introduction

Conclusions

References

Tables

Figures

14

$\rightarrow 1$

4

Back

Close

Printer-friendly Version

Interactive Discussion 


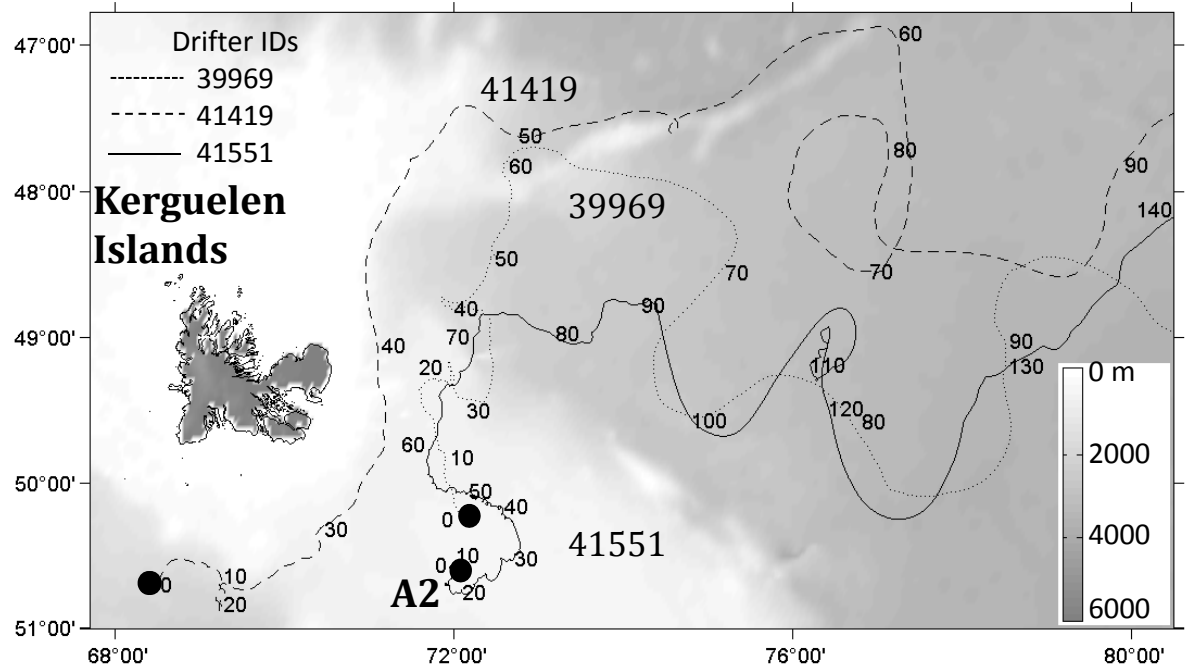

Fig. 4. Trajectories of 3 drifters $(39969,41419,41551)$ showing offshelf transport and elapse time along their trajectories. Drifter 41419 represents the pathway of a shelfbreak current, and drifters 39969 and 41551 represent pathways of direct offshelf transport from the Kerguelen plateau. The black dots indicate the location of deployments, and numbers next to trajectories are elapse time (days) after deployments.

\section{BGD}

11, 6845-6876, 2014

Surface currents and upwelling in

Kerguelen Plateau

regions

\section{Zhou et al.}

\section{Title Page}

\section{Abstract}

Introduction

Conclusions

References

Tables

Figures

14

$>$ I

4

Back

Close

\section{Full Screen / Esc}

Printer-friendly Version

Interactive Discussion 


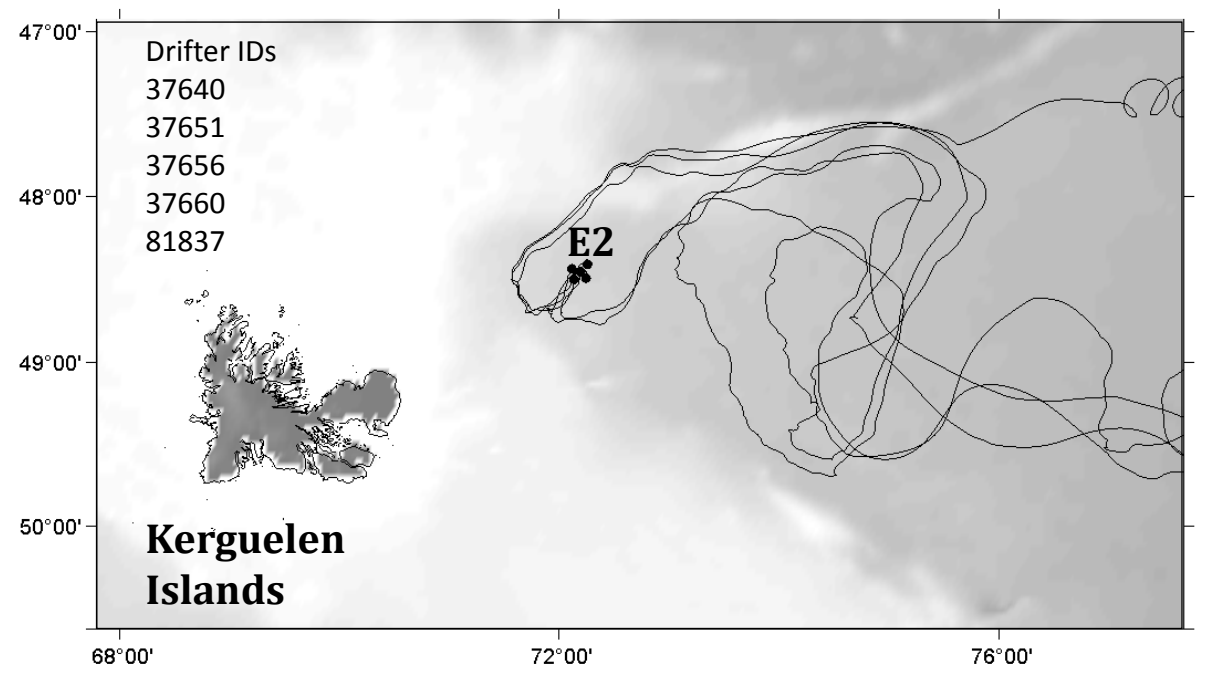

Fig. 5. Trajectories of 5 drifters $(37640,37651,37656,37660$ and 81837$)$ which were deployed in a grid less than $10 \mathrm{~km}$ within a time window less than $2.5 \mathrm{~h}$. The trajectories show a classic bifurcation demonstrating the stability of the shelfbreak current entrapping surrounding waters and current divergence near the deployment location.

\section{BGD}

$11,6845-6876,2014$

Surface currents and upwelling in

Kerguelen Plateau regions

\section{Zhou et al.}

\section{Title Page}

Abstract

Conclusions

Tables

14

Back
Introduction

References

Figures

$\rightarrow 1$

Close
Full Screen / Esc

Printer-friendly Version

Interactive Discussion 


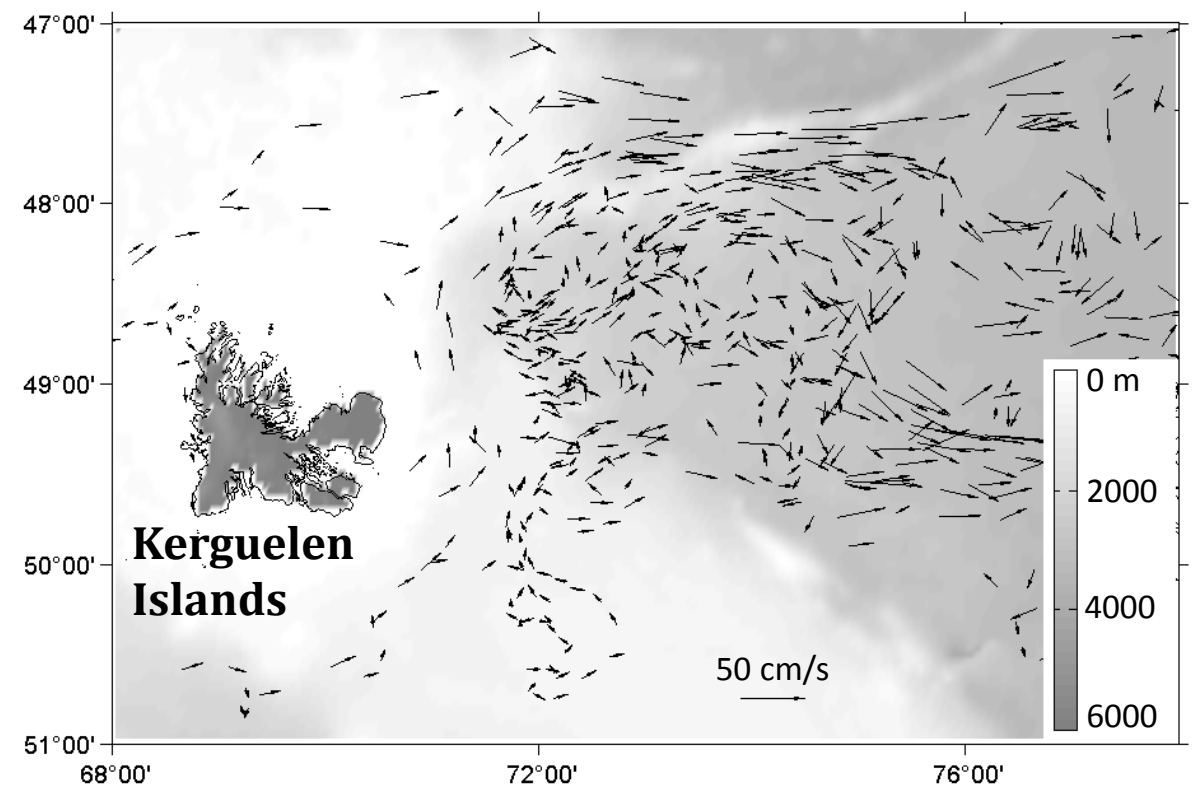

Fig. 6. 4 day mean currents in the study area from SVP drifters deployed during the cruise.

\section{BGD}

11, 6845-6876, 2014

Surface currents and upwelling in

Kerguelen Plateau regions

\section{Zhou et al.}

\section{Title Page}

\section{Abstract}

Introduction

Conclusions

References

Tables

Figures

14

$>$ I

4

Back

Close

\section{Full Screen / Esc}

Printer-friendly Version

Interactive Discussion 

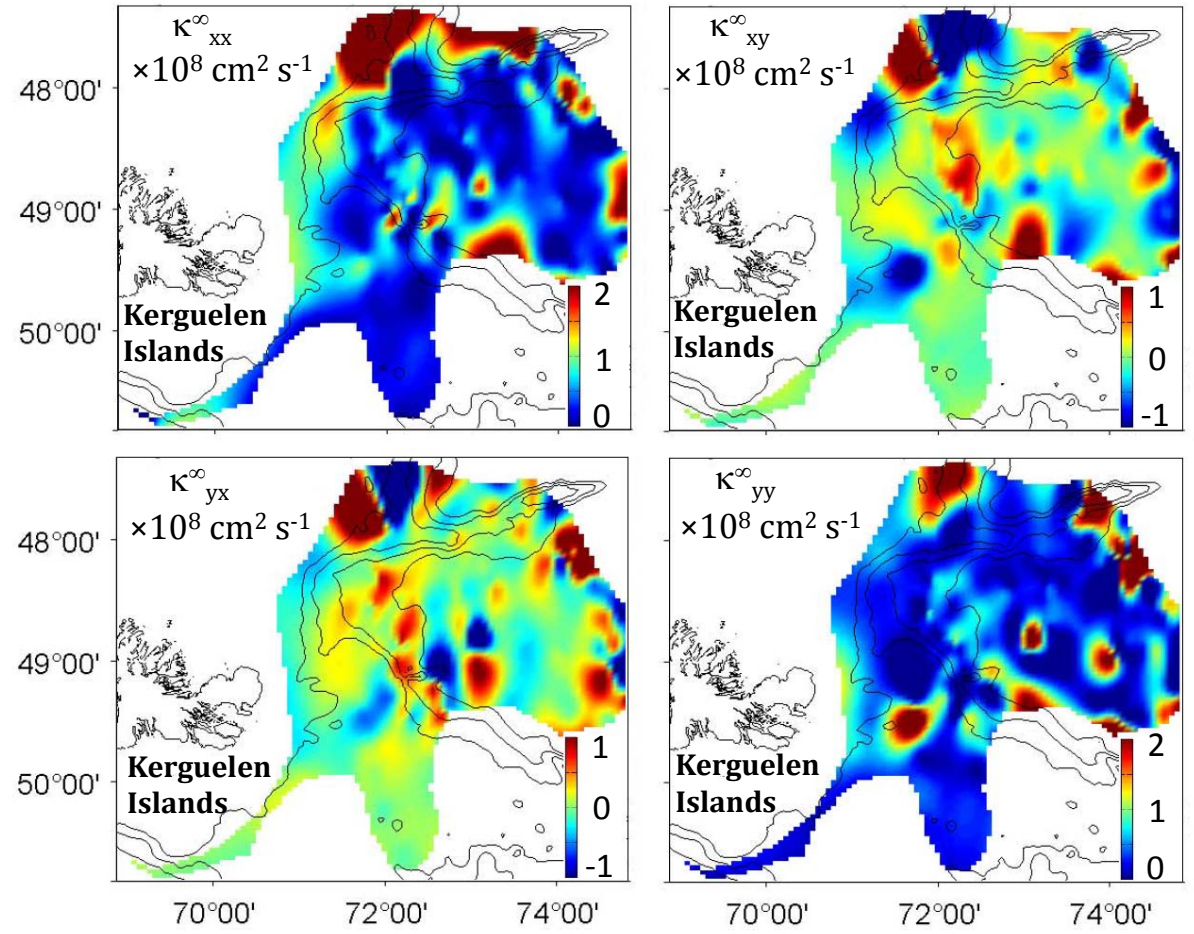

Fig. 7. Horizontal diffusivity tensor defined by $k(x)=\left\langle v_{i}^{\prime}\left(t_{0} \mid x, t_{0}\right) d_{j}^{\prime}\left(t_{0}-t \mid x, t_{0}\right)\right\rangle$ and $\kappa^{\infty}(x) \kappa(x, t \rightarrow \infty) \approx k\left(x, t \infty \tau^{\infty}\right)(i, j=x, y)$.

\section{BGD}

11, 6845-6876, 2014

Surface currents and upwelling in

Kerguelen Plateau regions

\section{Zhou et al.}

\section{Title Page}

\section{Abstract}

Introduction

Conclusions

References

Tables

Figures

14

$\rightarrow 1$

4

Back

Close

\section{Full Screen / Esc}

Printer-friendly Version

Interactive Discussion 


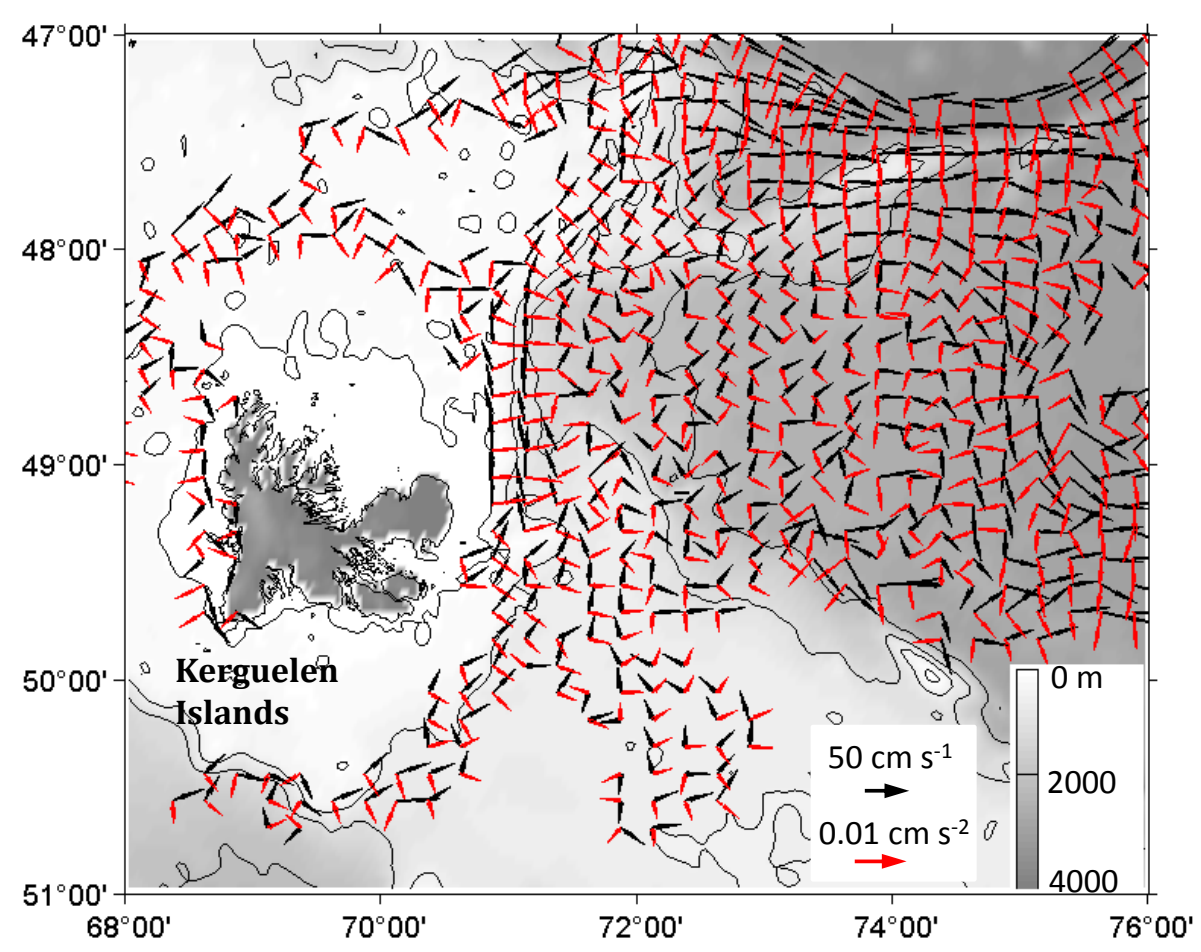

Fig. 8. Binned mean currents from SVP drifters (black arrows) and apparent sea surface gradients $(\mathrm{d} u / \mathrm{d} t-f v, \mathrm{~d} v / \mathrm{d} t+f u)$ (red arrows).

\section{BGD}

11, 6845-6876, 2014

Surface currents and upwelling in

\section{Kerguelen Plateau regions}

M. Zhou et al.

Title Page

Abstract

Introduction

Conclusions

References

Tables

Figures

14

Back

Full Screen / Esc

Printer-friendly Version

Interactive Discussion 


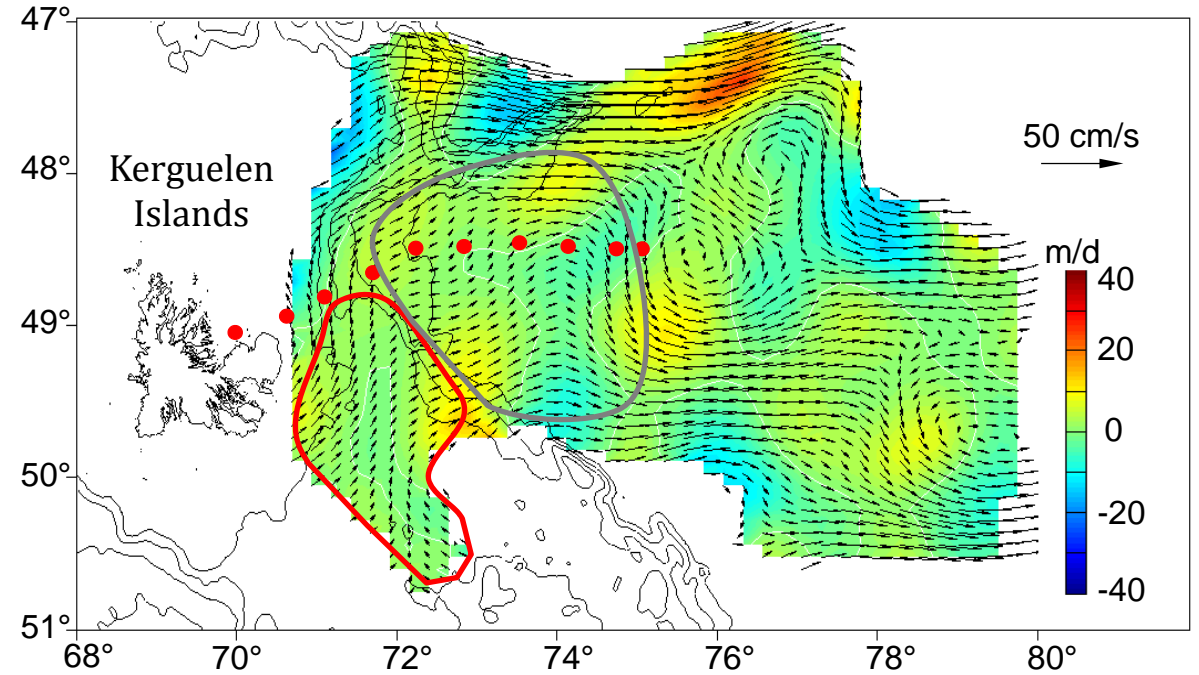

Fig. 9. The geostrophic currents estimated from drifter data (arrows) and the upwelling velocities estimated (false colors). Depth contours are 500, 1000, 1500 and $2000 \mathrm{~m}$. Red dots are CTD stations for the transect in Fig. 10. The areal mean upwelling velocities on the plateau and in the deep basin circled by the red and gray enclosed curves are computed approximately $3.3 \mathrm{md}^{-1}$ and $3.9 \mathrm{md}^{-1}$, respectively, and the upwelling volume fluxes in the circled plateau and basin areas are 0.7 and $1.1 \mathrm{~Sv}$, respectively. The mean and std of vertical velocities averaged in the combined plateau and basin area are $3.2 \pm 7.4 \mathrm{md}^{-1}$.
BGD

$11,6845-6876,2014$

Surface currents and upwelling in

Kerguelen Plateau

regions

M. Zhou et al.

\section{Title Page}

\section{Abstract}

Introduction

Conclusions

References

Tables

Figures

14

Back

Close

Printer-friendly Version

Interactive Discussion 

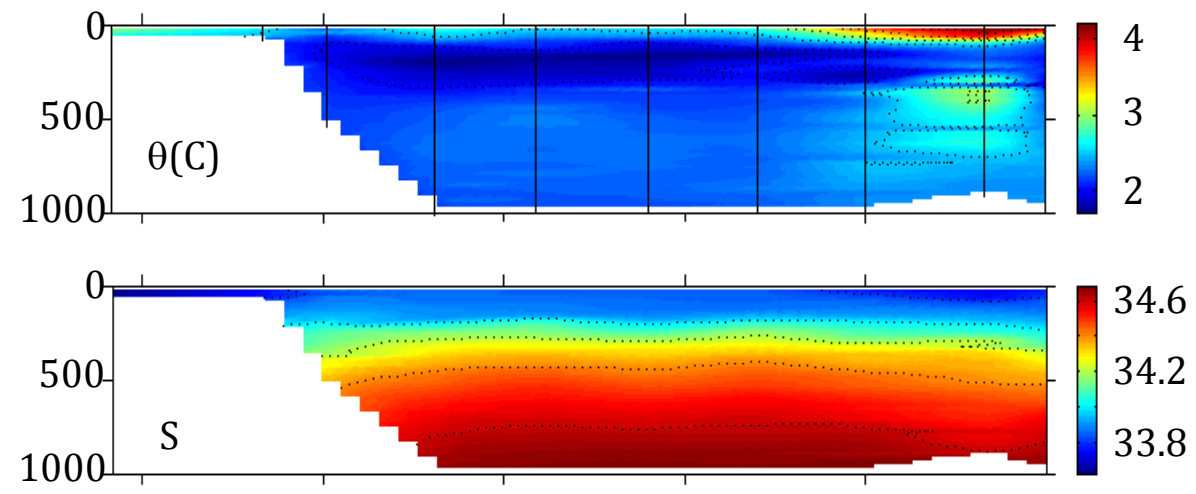

4.6

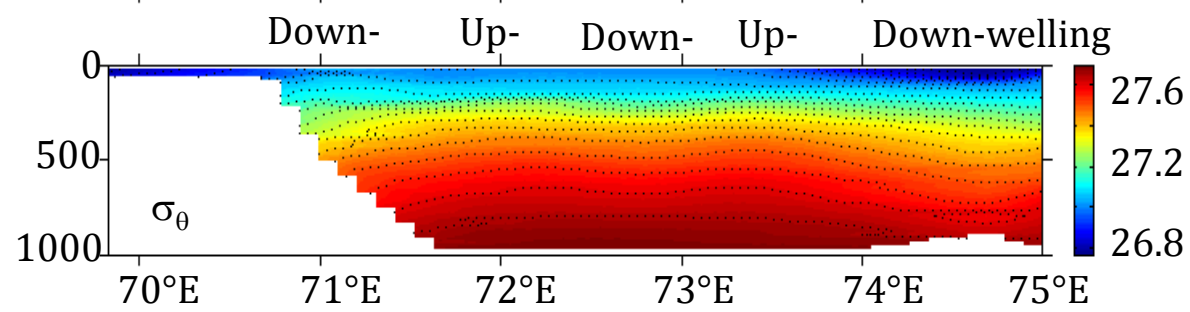

27.6

27.2

6.8

Fig. 10. West-East transects of potential temperature $(\theta)$, salinity $(S)$, and potential density $\left(\sigma_{\theta}\right)$.

\section{BGD}

11, 6845-6876, 2014

Surface currents and upwelling in

Kerguelen Plateau regions

\section{Zhou et al.}

Title Page

Abstract

Introduction

Conclusions

References

Tables

Figures

14

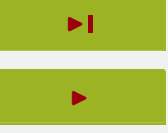

Back

Close

Full Screen / Esc

Printer-friendly Version

Interactive Discussion 


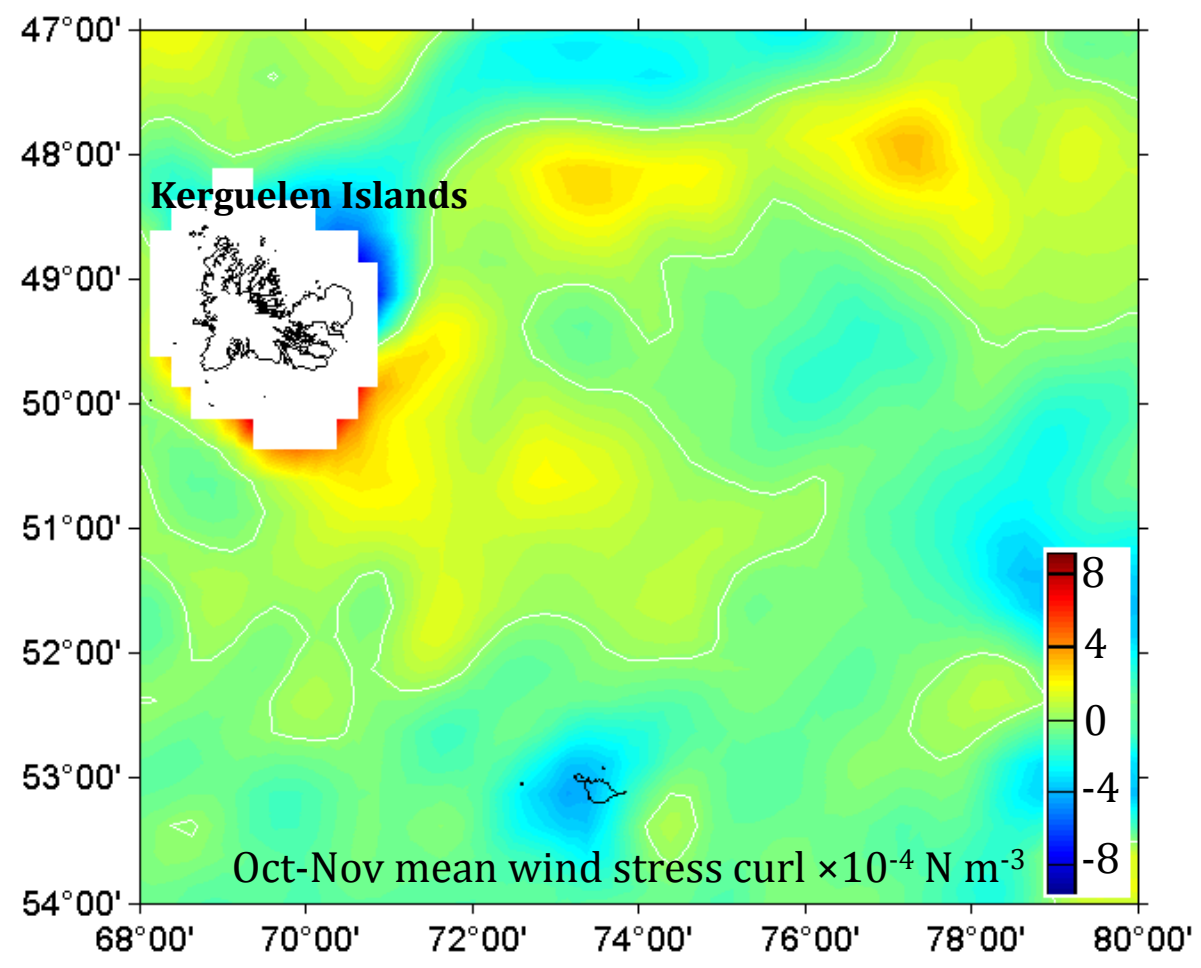

Fig. 11. Mean wind stress curl in the Kerguelen Plateau and East Kerguelen Basin from QuikSCAT data products (O'Neill et al., 2005; Risien and Chelton, 2008).

\section{BGD}

11, 6845-6876, 2014

Surface currents and upwelling in

Kerguelen Plateau

regions

\section{Zhou et al.}

\section{Title Page}

\section{Abstract}

Introduction

Conclusions

References

Tables

Figures

14

4

Back

Full Screen / Esc

Printer-friendly Version

Interactive Discussion 